\title{
Mesoscale Analysis on the Asymmetric Rainband of Typhoon Matmo (2014) and the Related Weather Situations for the GE222 Aircraft Crash Case
}

\author{
Tai-Hwa Hor ${ }^{1, *}$, Chih-Hsien Wei ${ }^{2}$, Yi-Sheng Chen ${ }^{3}$, Tian-Yow Shyu ${ }^{1}$ \\ ${ }^{1}$ General Education Center, Lunghwa University of Science and Technology, Guishan, Taoyuan 333, Taiwan \\ ${ }^{2}$ Flight Dispatch Department, China Airlines, Dayuan, Taoyuan 337, Taiwan \\ ${ }^{3}$ Weather Wing, ROC Air Force, Songshan, Taipei 105, Taiwan
}

Received June 10, 2020; Revised July 14, 2020; Accepted July 24, 2020

Copyright $\bigcirc 2020$ by authors, all rights reserved. Authors agree that this article remains permanently open access under the terms of the Creative Commons Attribution License 4.0 International License

\begin{abstract}
Typhoon Matmo (2014) was formed over the Central Pacific Ocean on 18 July 2014, and later, it became moderate in intensity $(32.7 \sim 50.9 \mathrm{~m} / \mathrm{s})$ with maximum wind speed of $38 \mathrm{~m} / \mathrm{s}$. After it landed the southeast coast of China, the typhoon circulation showed an asymmetric pattern in dipole wind field based upon the composite mean winds at $925 \mathrm{hPa}$ in use of NCEP/NCAR reanalysis data and NOAA/ESRL atmospheric variables plotting approach. The wind dipole feature was due to the steep gradient of the geopotential height anomaly at the east flank of the typhoon circulation and the friction effect at its lowest levels over land from the synoptic scale point of view. The study focuses on investigating the characteristics of the line echo wave pattern (LEWP) embedded within the typhoon rainband through the multi-scale processes, and try to realize the possible causes of crash event from the meteorological point of view for TransAsia Airways GE222 occurrence at Makung Airport influenced by the LEWPs in use of mesonet surface analysis based on 1-minute interval data measured by Makung Airport weather station and dual-Doppler radar analysis composited from Makung and Chiku weather radar data. The preliminary results delineated that the wave-like echoes organized by deep convections featured a key factor on the development of short duration heavy rainfall, low visibility and significant turbulence from the mesoscale point of view. Conclusively speaking, the aircraft faced multiple and severe weather situations, including the intense crosswind, obvious downdraft and extremely low visibility. Therefore, the impact of deep convections inside LEWPs embedded within the typhoon rainband on aviation safety was remarkable, and this case is a good lesson for flight safety.
\end{abstract}

Keywords LEWP, Rainband, Wind Dipole, Mesonet Surface Analysis, Dual-Doppler Radar Analysis

\section{Introduction}

In sub-tropical ocean area, the weather systems are different with those in mid-latitudes. For instance, the rainband embedded within a tropical cyclone is an important phenomenon owing to its significant effect on quantitative and qualitative rainfall. Hor et al. [1] found that while Typhoon Otto (1998) was over the open ocean, it appeared inner and outer rainbands, and the vertical cross sections along the radial showed that the outer rainband tilted outward and were more intense than the inner one. Wei et al. [2] mentioned that the vertical kinematic characteristics of the rainband in Typhoon Morakot (2009) revealed two types of downdrafts, namely inner-edge and low-level downdrafts. Moreover, Yu et al. [3, 4] learned that the outer areas of tropical cyclones usually possessed larger convective available potential energy and lower humidity than the inner-core environment, and rainbands in the tropical cyclones could develop squall-line-like airflow structures and a low-level cold-pool signature. Furthermore, most of outer rainbands (more than 50\%) were characterized by convective precipitation, a convergence zone between the band-relative rear-to-front flow and the front-to-rear flow at low levels, and a surface cold pool signature. Also, Wei et al. [5] studied the interaction between southwesterly flow and typhoon circulation by using radar observations might contribute to the development of rainbands as well as the intensification of the inward radial flow embedded within typhoon during the passage of Typhoon Morakot (2009) over Taiwan.

On 23 July 2014, TransAsia Airways passenger flight GE222, an ATR-72 airplane, took off from Kaohsiung 
International Airport for Makung Airport in Penghu County. There were 58 people on board, including 2 flight crewmembers, 2 cabin crewmembers and 54 passengers. The aircraft crashed in Xixi Village near Makung Airport in Punghu Island at 1906 LST (UTC+8) when conducting the RWY 20 VOR approach, caused 48 fatalities and 10 serious injuries, 5 residents on ground suffered minor injuries based upon the ASC Aviation Occurrence Report [6].

The FDR (flight data recorder) flight path versus wreckage map during the last 34 seconds for TransAsia Airways GE222 Occurrence told that during the last approach stage (in period of 34 seconds) the plane seriously deviated from its regular route due to some reasons. At that time the aircraft was penetrating a line echo wave pattern (LEWP) in typhoon rainband. Previous studies $[7,8]$ depicted that the LEWPs embedded within a subtropical mesoscale convective system in East Asia featured the mesoscale bow echoes, including weak echo channel, rear-inflow notch and rear-inflow jet. Also, the bookend vortices in the LEWP system during the interaction between southwesterly monsoonal flow and typhoon circulation were similar to the bow echo pattern, and the impact of convections inside LEWPs on aviation safety was remarkable. However, more detailed investigation needs to step forward in order to identify the realistic meteorological scenario through the multi-scale processes based upon routine synoptic weather observations, satellite imageries, NCEP/NCAR reanalysis, the mesonet analysis and dual-Doppler radar analysis. The following research questions are raised to figure out the formation of the LEWP system, its structure and related threats on aviation. Therefore, the goals of this study will cover:

a. Describe the characteristics of the line echo wave pattern embedded within the rainband of Typhoon Matmo (2014) through the multi-scale processes.

b. Realize the possible causes of crash event for TransAsia Airways GE222 Occurrence at Makung Airport from the perspective of mesoscale weather analysis in order to prevent the accident happens again.

\section{Synoptic Weather Analysis}

\subsection{Data Resources}

By using the weather observation data, radar data, satellite imageries adopted from the Central Weather Bureau as well as NCEP/NCAR reanalysis data, this study investigates the notable wind dipole phenomenon associated with the circulation of Typhoon Matmo (2014). Also, it tries to delineate the characteristics of the line echo wave pattern embedded within the typhoon rainband, and the related weather conditions in the lower atmosphere over the central Taiwan and Punghu areas after Typhoon Matmo landed the coastal line of Mainland China.

\subsection{Synoptic Weather Patterns}

The typhoon motions were usually guided by the synoptic scale weather systems, especially those over the Northwest Pacific Ocean which were primarily influenced by the sub-tropic high systems. The surface weather maps in Figure 1(a) (0000UTC on 22 July 2014) and Figure 1(b) (1200UTC on 23 July 2014) mentioned that the sub-tropic high over the Northwest Pacific Ocean shifted eastward gradually and its ridge extended from north to south, reaching the $130^{\circ} \mathrm{E}$ line. The weather pattern kept Typhoon Matmo (2014) propagating north-northwestward in moderate intensity with maximum wind speed of $38 \mathrm{~m} / \mathrm{s}$ and $960 \mathrm{hPa}$ in minimum pressure. Typhoon Matmo (2014) was formed over the Central Pacific Ocean on 18 July 2014, and it became well organized and upgraded from tropical storm category (34 63 kts) to moderate category (64 99 kts) in intensity on 19 July. Its best track was shown in Figure 2 analyzed by the Central Weather Bureau [9]. This typhoon invaded the east coast of Taiwan at 0010TST (UTC+8) on 23 July 2014 and 15 hours later, it landed the east coast of Fujian Province of China at 1500TST $($ UTC +8$)$ on 23 July 2014. Himawari IR satellite image at 1900TST (UTC+8) on 23 July 2014 indicated that the typhoon center had moved inland with clear rainbands at its south flank.

During the passage of the typhoon over Taiwan Strait, the typhoon circulation possessed two typical weather phenomena: the wind dipole feature in asymmetric shape and the extremely heavy rainfall event induced by the line echo wave pattern embedded within the typhoon rainband. These two situations will be investigated later in use of NCEP/NCAR reanalysis data, skew $\mathrm{T} \log \mathrm{P}$ diagram, mesonet surface data, and dual-Doppler radar data. 


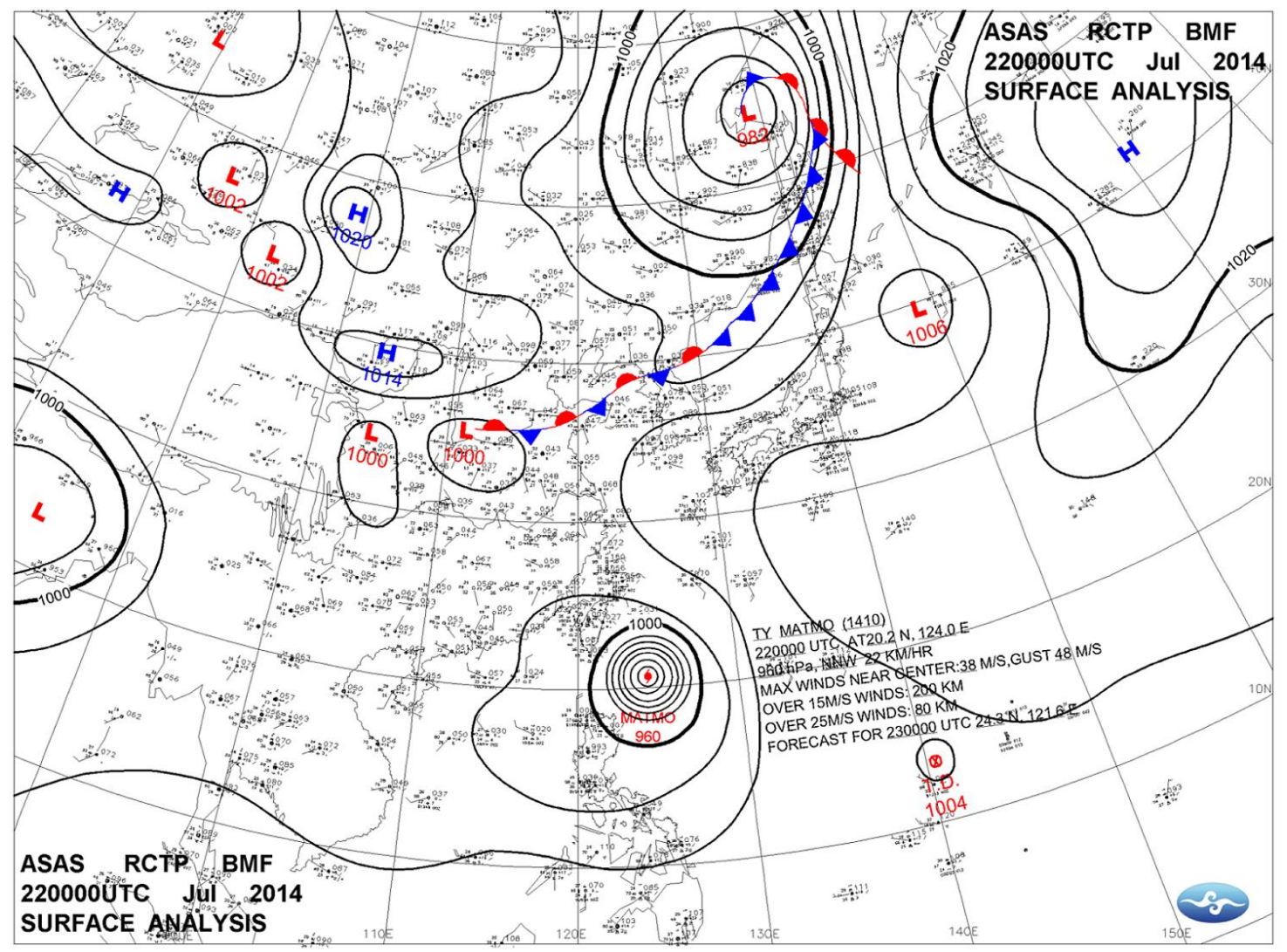

a

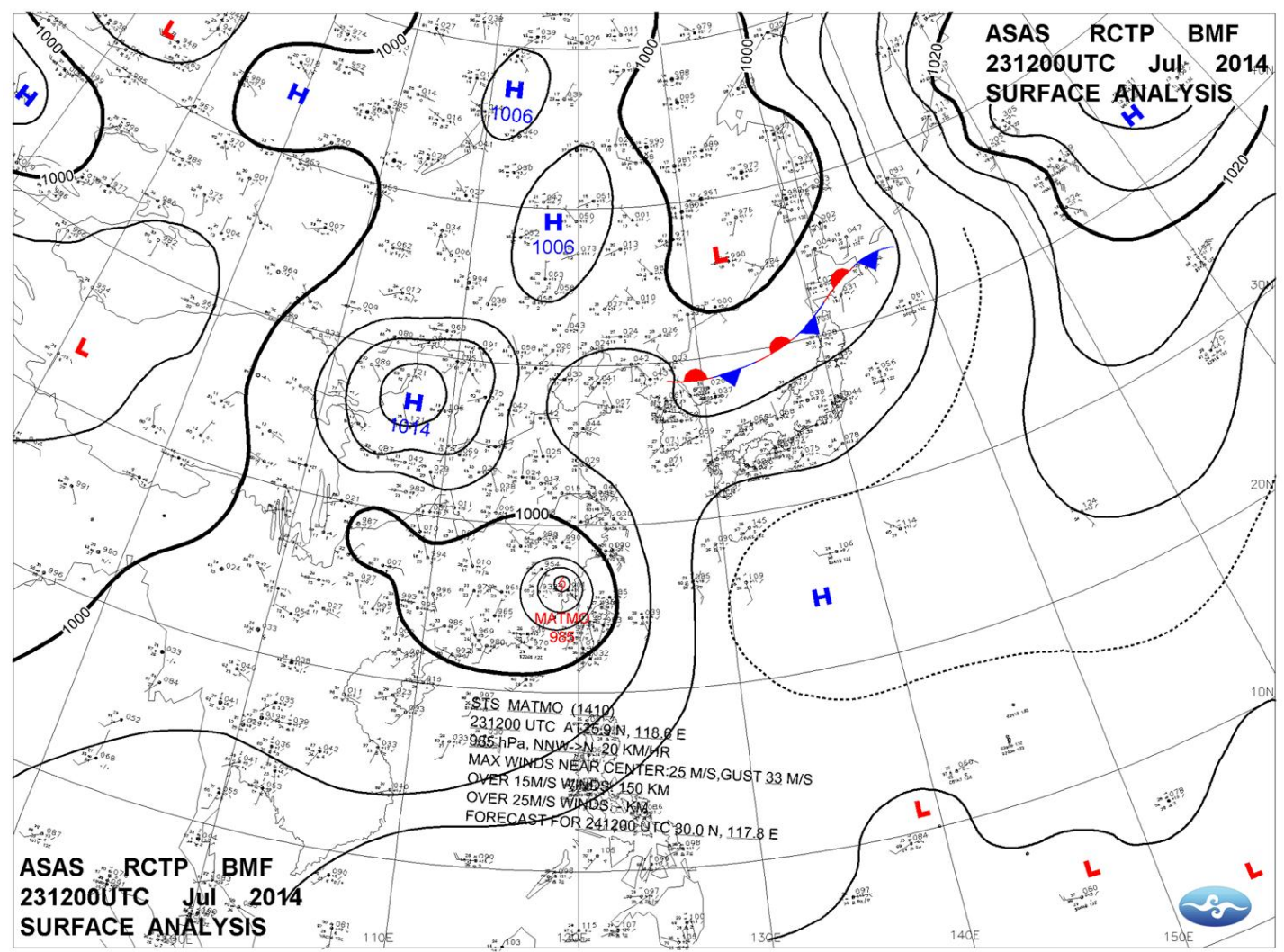

Figure 1. The surface weather maps at (a) 0000 UTC (0800TST) on 22 July 2014 and (b) 1200UTC (2000TST) on 23 July 2014. (Adopted from Central Weather Bureau) 


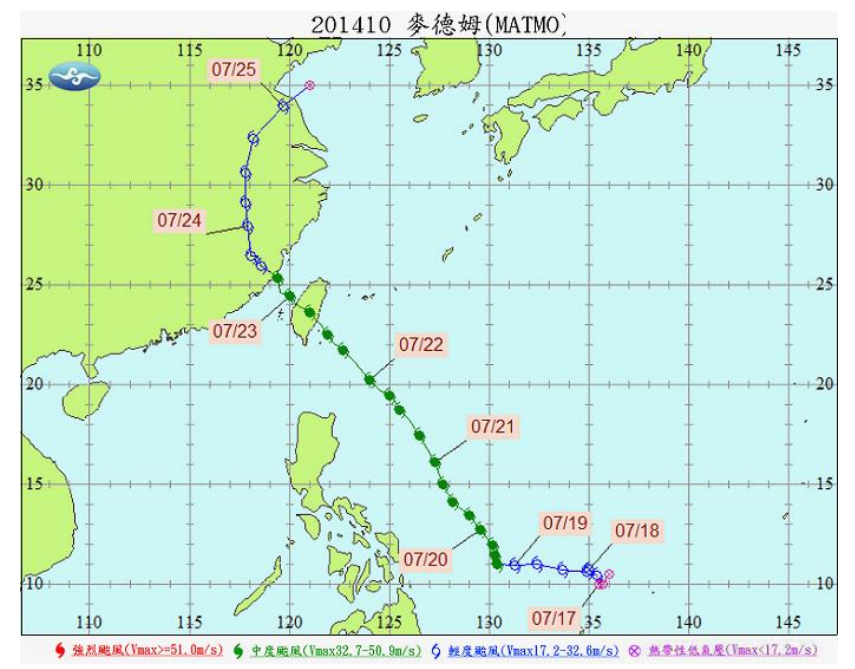

Figure 2. The best track analyzed by the Central Weather Bureau. Typhoon Matmo moved into the mainland China at 1500TST (UTC+8) on 23 July 2014.The center of Typhoon Matmo at 1200UTC (2000TST) of 23 July 2014 was located at the spot of $25.9^{\circ} \mathrm{N}$ and $118.6^{\circ} \mathrm{E}$.

\subsection{Dipole Wind Feature}

Typhoon Matmo (2014) was formed over the Central Pacific Ocean on 18 July 2014, and it became moderate in intensity on 19 July 2014. The typhoon kept the same intensity moving over the Taiwan Island and propagating toward the Fujian Province of China between 0010TST $(\mathrm{UTC}+8)$ and 2000TST (UTC+8) on 23 July 2014. Figure 3 delineates the composite mean winds $(\mathrm{m} / \mathrm{s})$ at $925 \mathrm{mb}$ between EQ- $45^{\circ} \mathrm{N}$ and $90^{\circ} \mathrm{E}-140^{\circ} \mathrm{E}$ at $1200 \mathrm{UTC}$ (2000TST) on 23 July 2014 in use of NCEP/NCAR reanalysis data. It shows an asymmetric pattern in dipole wind field. The intensity of wind speed at the right flank in maximum of $18 \mathrm{~m} / \mathrm{s}$ associated with the typhoon circulation over the open ocean was much higher than that at the left flank in maximum of $8 \mathrm{~m} / \mathrm{s}$ which was affected by the friction effect at the lowest levels of its circulation over land. Also, the merging mechanism between the typhoon circulation and the southwesterly flow as well as the blocking effect influenced by Taiwan high terrain triggered the locally intense wind field in maximum of 16 $\mathrm{m} / \mathrm{s}$ over the southwest coast of Taiwan. This intense wind field companied with the extremely heavy rainfall and downward/upward flows inside the typhoon rainband might hint a relationship to the TransAsia Airways GE222 Occurrence at Makung Airport at 1906TST (UTC+8) on 24 July 2014.

Further investigation shown in Figure 4 portrayed that the geopotential height anomaly (gpm) between $25.5^{\circ} \mathrm{N}-26.5^{\circ} \mathrm{N}$ and $117^{\circ} \mathrm{E}-127^{\circ} \mathrm{E}$ at $1200 \mathrm{UTC}$ on 23 July 2014. The lower atmosphere in the typhoon circulation depicted the convergent phenomenon and the vice versa in the upper one. Also, the east side of anomaly sketched a sharp gradient between $121^{\circ} \mathrm{E}$ and $127^{\circ} \mathrm{E}$ at the lower levels, corresponding to the intense wind field of the dipole, as the west side of anomaly became quite uniform between $117^{\circ} \mathrm{E}$ and $121^{\circ} \mathrm{E}$, corresponding to the weak wind field of the dipole, while the typhoon center was located at the spot of $25.9^{\circ} \mathrm{N}$ and $118.6^{\circ} \mathrm{E}$. Moreover, in the vicinity of the typhoon center there was the highest relative humidity with maximum of $100 \%$ which was depicted in Figure 5, telling the composite mean surface relative humidity $(\%)$ between EQ- $45^{\circ} \mathrm{N}$ and $90^{\circ} \mathrm{E}-140^{\circ} \mathrm{E}$ on 1200UTC, 23 July 2014. Again, the combination of Figures 3 and 5 showed that the prevailing southwesterly flow in plenty of moist air over the South China Sea transported northeastward, supporting the development of typhoon rainbands embedded within typhoon circulation.

In summary, the steep gradient of the geopotential height anomaly at the east flank of the typhoon circulation and the friction effect at its lowest levels over land (at the west flank) sketched the dipole wind feature critically.

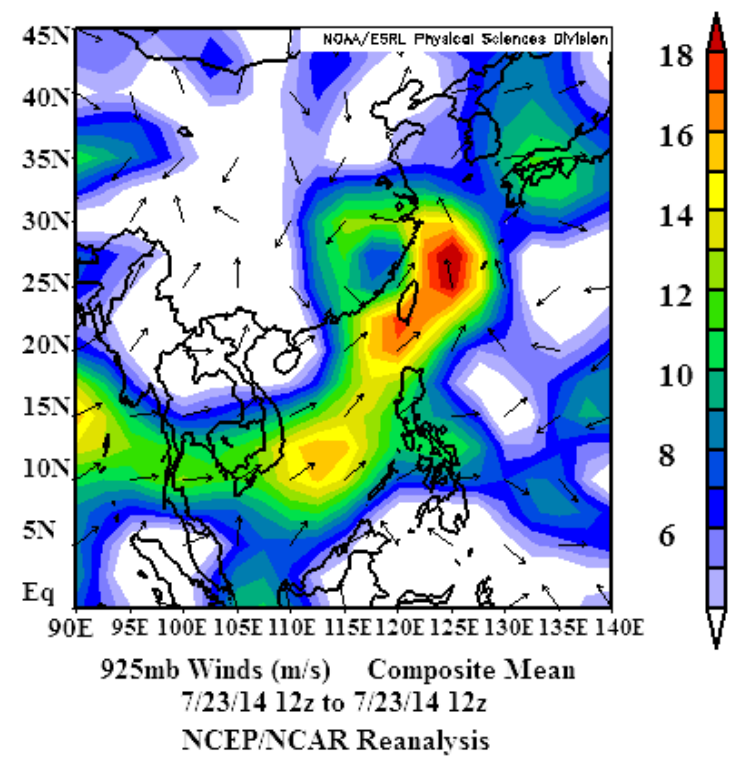

Figure 3. Composite mean winds $(\mathrm{m} / \mathrm{s})$ at $925 \mathrm{mb}$ between EQ- $45^{\circ} \mathrm{N}$ and $90^{\circ} \mathrm{E}-140^{\circ} \mathrm{E}$ on $1200 \mathrm{UTC}$ (2000TST), 23 July 2014. (Resulted from NOAA/ESRL[10])

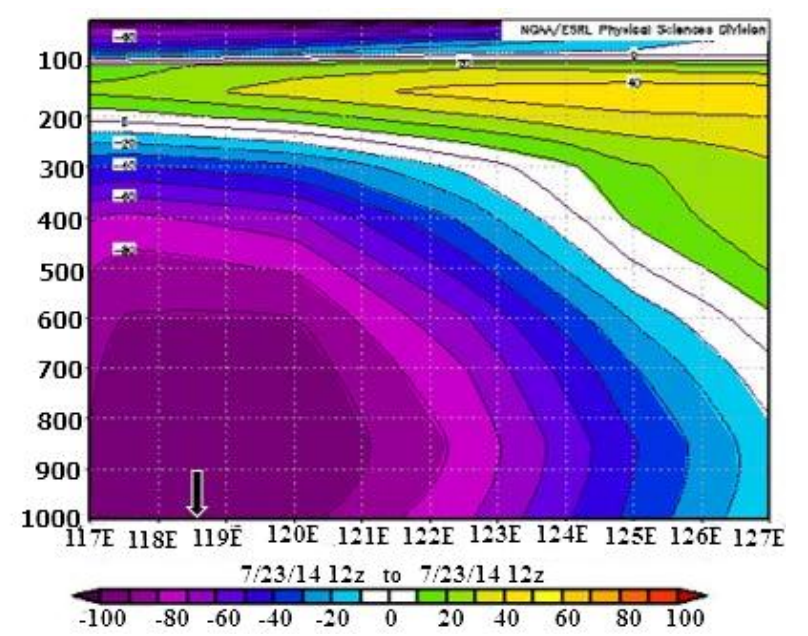

Figure 4. Geopotential height anomaly (gpm) between $25.5^{\circ} \mathrm{N}-26.5^{\circ} \mathrm{N}$ and $117^{\circ} \mathrm{E}-127^{\circ} \mathrm{E}$ at $1200 \mathrm{UTC}$ (2000TST) on 23 July 2014. The black arrow stands for the location of $25.9^{\circ} \mathrm{N}$ and $118.6^{\circ} \mathrm{E}$, the center of Typhoon Matmo at 1200UTC of 23 July 2014. (Resulted from NOAA/ESRL [10]) 


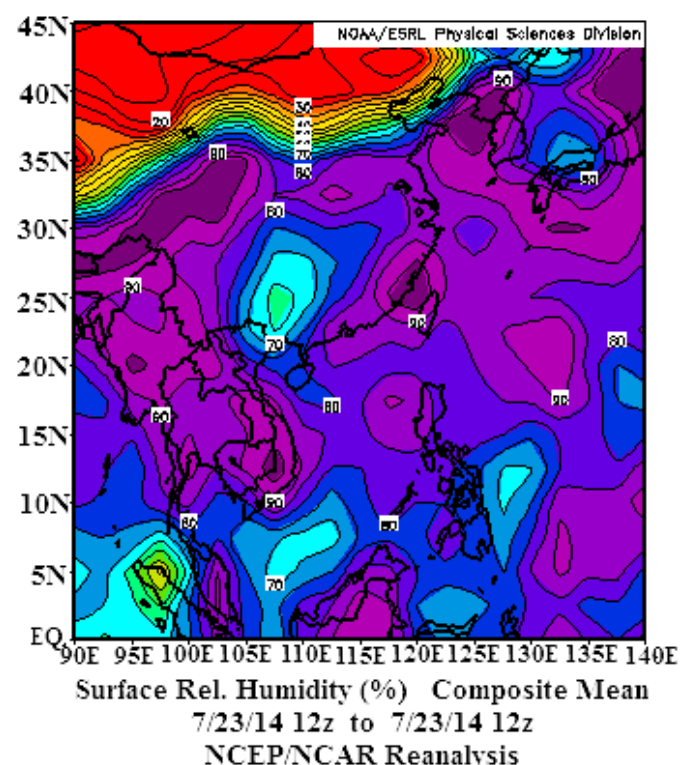

100

90

80

70

60

50

40

Figure 5. Composite mean surface relative humidity (\%) between EQ- $45^{\circ} \mathrm{N}$ and $90^{\circ} \mathrm{E}-140^{\circ} \mathrm{E}$ on 1200UTC (2000TST), 23 July 2014. (Resulted from NOAA/ESRL [10])

\section{Mesonet Weather Analysis}

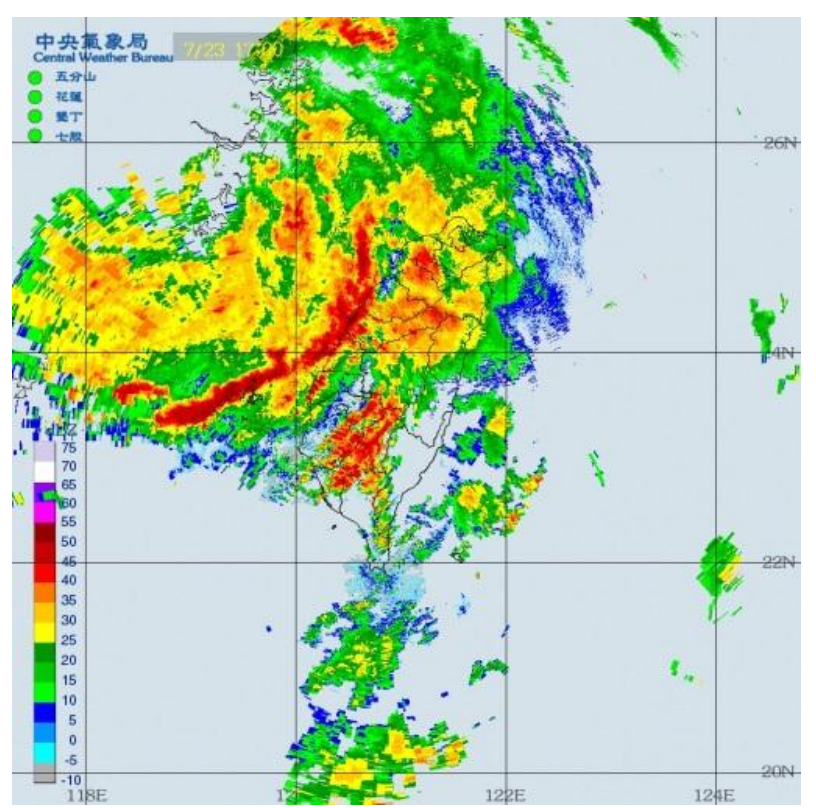

(a)
After Typhoon Matmo(2014) passed over the Central Mountain Range of Taiwan, the well-defined convective cells embedded within the outer rainband triggered several line echo wave patterns (LEWP) in the northeast-southwest orientation moving northeastward. Figure 6(a) delineates the composite radar reflectivity images in $\mathrm{dBZ}$ that several echo waves embedded within the typhoon rainband were going to pass over the Penghu Island and coastal areas of central Taiwan at 1700TST on 23 July 2014, about 2 hours before the TransAsia Airways GE222 occurrence. Figures 6(b) 6(d) mentioned the following radar pictures at 1800, 1900 and 2000TST on 23 July 2014. The LEWP embedded within the outer rainband propagated northeastward and its intensity of radar reflectivity reached more than $45 \mathrm{dBZ}$. The study tried to focus on the mesoscale analysis of convective cells in the line echo wave pattern embedded within the rainband by using mesonet surface data and dual-Doppler radar data.

Sixteen weather stations operated by Central Weather Bureau along the western coast of central Taiwan in the southwest-northeast orientation (from Fangyua to Jhuna, shown in Figure 7) were selected to identify the distribution of hourly rainfall rate and surface temperature during the passage of LEWP on 23 July 2014 (shown in Figure 8).

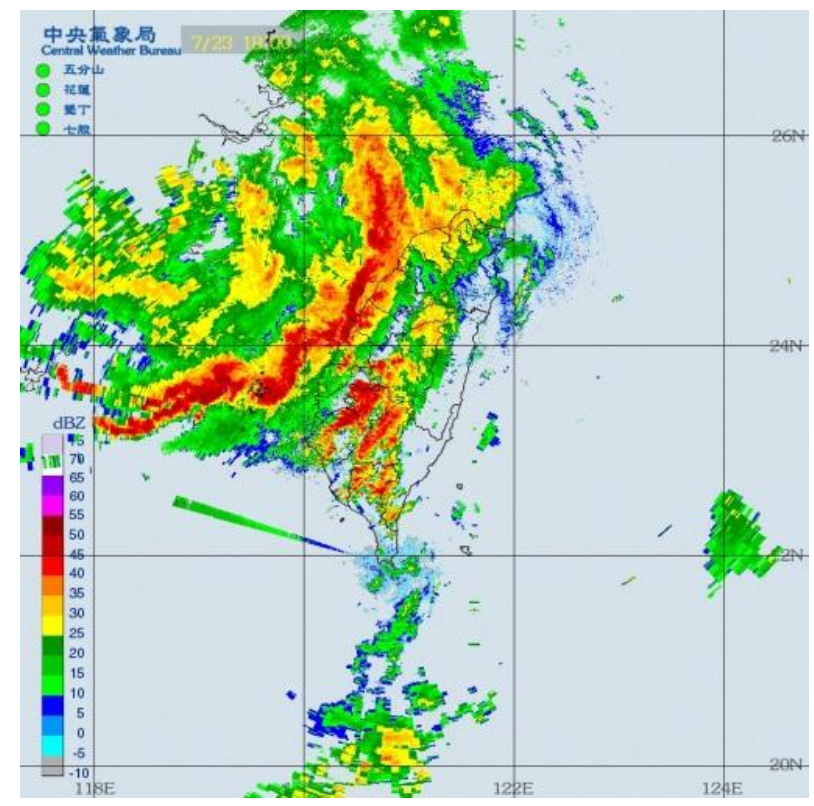

(b) 


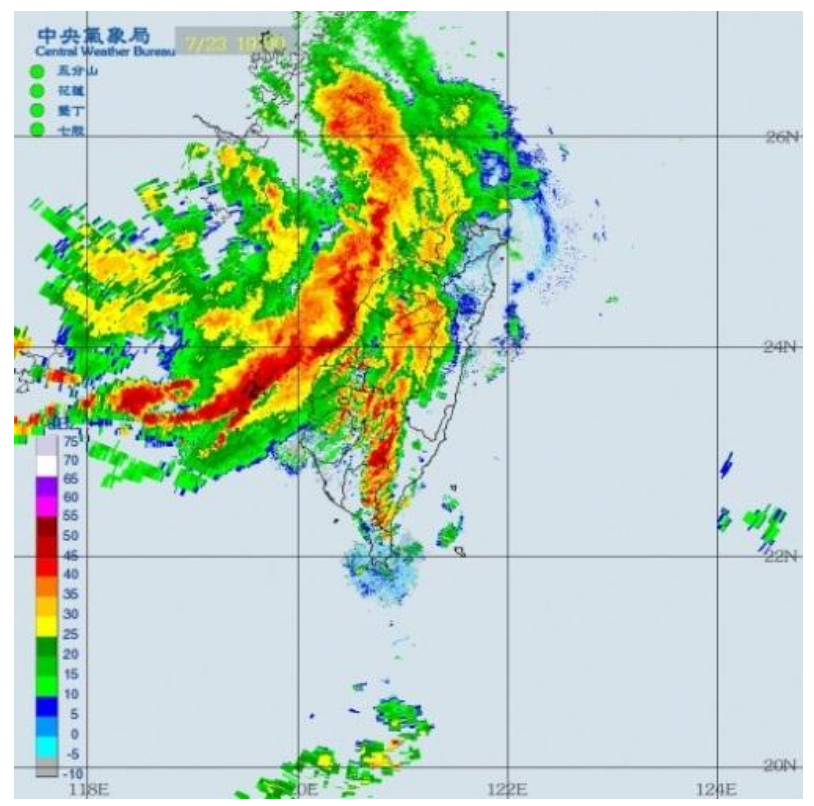

(c)

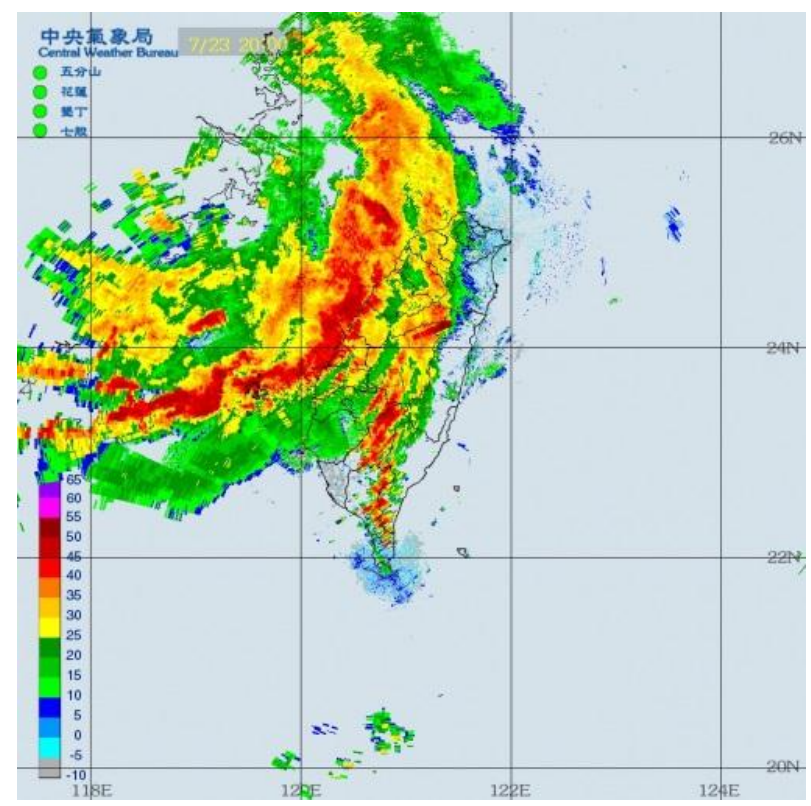

(v)

Figure 6. (a)The composite radar reflectivity images in $\mathrm{dBZ}$ indicated that three waves embedded within typhoon rainband passed over Makung Airport at 1700TST (UTC+8) on 23 July 2014, about 2 hours before the occurrence. (b) The same as (a) except at 1800TST (UTC+8) on 23 July 2014. (c) The same as (a) except at 1900TST (UTC+8) on 23 July 2014. (d) The same as (a) except at 2000TST (UTC+8) on 23 July 2014 . The red circle stands for the position of typhoon center. (Referred from Central Weather Bureau)

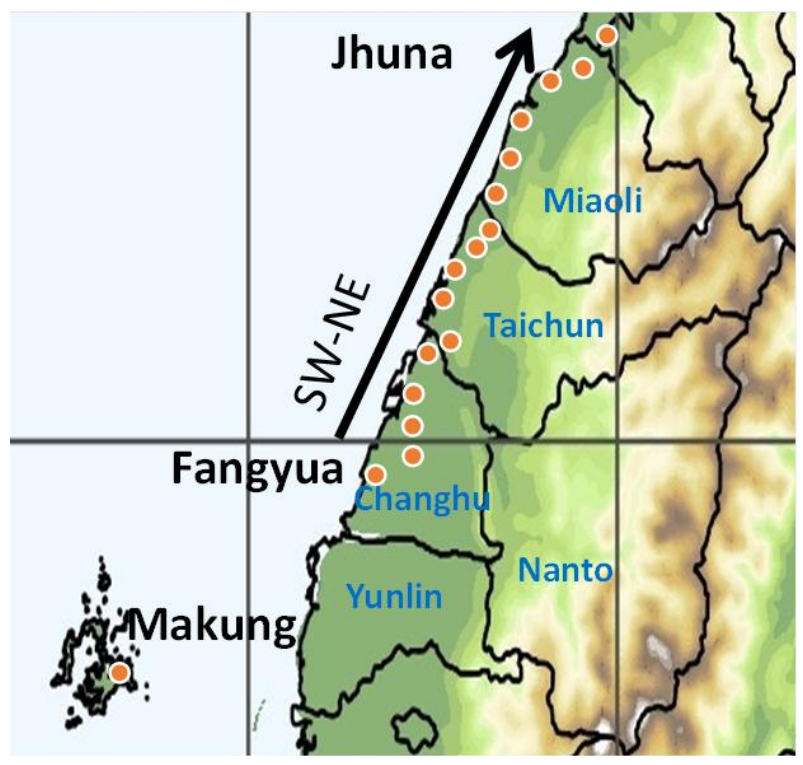

Figure 7. Sixteen weather stations operated by Central Weather Bureau along the western coast of central Taiwan in the southwest-northeast orientation. The data of hourly rainfall and surface temperature of the stations will be analyzed in Figure 8 . 


\begin{tabular}{|c|c|c|c|c|c|c|c|c|c|c|c|c|c|c|c|c|}
\hline \multicolumn{2}{|c|}{ 2014.07.23 Fangyuan } & \multicolumn{2}{|c|}{ Puyan Fuxing } & \multicolumn{2}{|c|}{ Lukang Shenggang } & Longjing & Wuqi & Qingshui & Da-an & Dajia & Yuanli & Tongxiao & Xihu & Houlong & Zaogiao & Jhunan \\
\hline (TST) 24 & 0 & 0 & 0 & 0.5 & 0.5 & 0.5 & 0.5 & 0 & 0 & 0 & 0 & 0 & 0 & 0 & 0 & 0 \\
\hline 23 & 0 & 0.5 & 0.5 & 0.5 & 0.5 & 0 & & 0.5 & 0 & 0.5 & & 0 & 0 & 0 & 0 & 0 \\
\hline 22 & 2.5 & 1.5 & 2 & 3 & 7 & 18 & -75.5 & 26 & 33 & 26 & 30.5 & 33.5 & 35 & 30.5 & 5.5 & 5.5 \\
\hline 21 & 14.5 & 14.5 & 19.5 & 19 & 25.5 & & & 20.5 & 28.5 & 34 & 25.5 & 20.5 & 21.5 & 12.5 & 0 & 0 \\
\hline 20 & 2 & 2.5 & 4.5 & 9 & 21.5 & & 24 & 25 & 45.5 & 18 & 37 & 14.5 & 11.5 & 6.5 & 0.5 & 0.5 \\
\hline 19 & 1.5 & 0.5 & 2.5 & 11.5 & $4.5^{2}$ & 2 & 7.5 & 9.5 & 7.5 & 3.5 & 3.5 & 1.5 & 4 & 1.5 & 0 & 0.5 \\
\hline 18 & 13 & 4 & 10 & 11.5 & $7^{1.5}$ & 8 & 10 & 8.5 & 9 & 13 & 15 & 7 & 6.5 & 3 & 0.5 & 0 \\
\hline 17 & 3.5 & 4.5 & 26.5 & & & 20 & 21 & 16 & 16 & 7 & 10.5 & 2 & 1 & 1 & 0.5 & 1 \\
\hline 16 & 2.5 & 3 & & & 10.5 & 10.5 & 16 & 10 & 12 & 17 & 10.5 & 6 & 7 & 4 & 1.5 & 1.5 \\
\hline 15 & 16.5 & 8.5 & 11 & & 6 & 3.5 & 2 & 0.5 & 0.5 & 1 & 0.5 & 1 & 1.5 & 1.5 & 0.5 & 0.5 \\
\hline
\end{tabular}

(a)

\begin{tabular}{|c|c|c|c|c|c|c|c|c|c|c|c|c|c|c|}
\hline Time & Temp $\left({ }^{\circ} \mathrm{C}\right)$ & Puyan & Fuxing & Lukang & Shenggang & Longing & Wuai & Oingshui & Da-an & Dajia & Yuanli & Tongxiao & Xihu & Houlong \\
\hline $\begin{array}{c}2014.07 .23 \\
\text { (TST) } 24\end{array}$ & 27.3 & 28.4 & 28.7 & 27. & $\quad 28.3$ & $\begin{array}{r}\text { Longjing } \\
28.2\end{array}$ & 28.2 & $\begin{array}{r}\text { Qingsinu1 } \\
28.4\end{array}$ & 28.9 & $\begin{array}{l}\text { Dafjia } \\
27.5\end{array}$ & 29.8 & 28.1 & 26.2 & 26.9 \\
\hline 23 & 27.4 & 28.7 & 28.9 & 26. & 28.4 & 28.5 & 27.8 & 28.2 & 28.7 & 26.7 & 29.6 & 27.7 & 25.1 & 25.4 \\
\hline 21 & 24.9 & 25.4 & 25.4 & 24. & 24.4 & 24.2 & & 23.8 & 24.3 & 23.1 & 24.4 & 23.6 & 24.1 & 24.3 \\
\hline 20 & 27.1 & 27.9 & 27.9 & 26. & 26.5 & 26.3 & & 25.3 & 25.4 & 24.7 & 25.0 & 23.8 & 24.3 & 24.8 \\
\hline 19 & 24.6 & 28.3 & 28.2 & 24. & 27.5 & 27.4 & & 27.7 & 28.0 & 26.2 & 28.5 & 27.5 & 25.0 & 25.5 \\
\hline 17 & 27.5 & 27.7 & 27.7 & 26. & 26.0 & & 25.7 & 25.0 & 25.9 & 24.8 & 26.6 & 26.5 & 24.4 & 24.8 \\
\hline 16 & 27.9 & 27.9 & 28.0 & 26. & & & 25.5 & 25.5 & 25.9 & 24.4 & 25.9 & 24.7 & 24.0 & 24.4 \\
\hline 15 & & 25.8 & 26.2 & 25. & & 25.6 & 25.7 & 26.0 & 26.4 & 24.9 & 27.1 & 26.4 & 24.9 & 25.5 \\
\hline
\end{tabular}

(b)

Figure 8. (a) The distribution of hourly rainfall rate ( $R R$ in unit of $\mathrm{mm} / \mathrm{hr}$ ) measured by $16 \mathrm{CWB}$ weather stations in SW-NE orientation along the western coast of the central Taiwan area on 23 July 2014. The blue arrows represent the transition of heavy rainfall cases. (b) The same as (a) except for the surface temperature $\left({ }^{\circ} \mathrm{C}\right)$. The blue arrows represent the transition of low temperature cases on 23 July 2014. "TST " stands for the Taiwan standard time (UTC+8).

Figure 8(a) describes the distribution of hourly rainfall rate ( $R R$ in unit of $\mathrm{mm} / \mathrm{hr}$ ) in southwest-northeast orientation along the western coast of the central Taiwan area between $1500 \sim 24$ TST (UTC+8) on 23 July 2014. The blue arrows represent the transition of heavy rainfall events related to the convective cells within the LEWP. It shows the most serious rainfall was occurred between 2000 and 2200TST. Also, Figure 8(b) points out the distribution of surface temperature $\left({ }^{\circ} \mathrm{C}\right)$ along the western coast of the central Taiwan area on 23 July 2014. The blue arrows represent the transition of locally abrupt temperature drops due to heavy rainfall events. Furthermore, the situations of the lowest temperature generally match the heavy rainfall events during the period of 2000 and 2200TST.

Based upon the preliminary findings, we learned that the wave-like echoes were quite similar to the bow echo pattern while the typhoon system kept moving north-northwestward. The mesonet surface data analysis told that each echo in the LEWP consisted of several convective cells bringing heavy rainfalls and resulting temperature drops on the ground along the west coast of Taiwan. Furthermore, according to Makung airport weather observations (Figure 9), there were three modes of LEWP approaching the airport, the abrupt wind change led the peak of rainfall at about 40 60 minutes, and the following temperature drop and pressure rise delayed the peak of rainfall at about another 35 60 minutes. The more detailed descriptions are following. The first LEWP mode touched the Makung airport at about 1600TST (UTC+8) with abrupt variation in wind direction and wind speed, and brought the rainfall peak of $14 \mathrm{~mm} / \mathrm{min}$ at about $1640 \mathrm{TST}$ (40 minutes time lag), resulting in temperature drop and pressure rise at about 1740TST (60 minutes time lag). Afterward, the second mode reached the Makung Airport at about 1735TST, and brought the rainfall peak of 26 $\mathrm{mm} / \mathrm{min}$ at about 60 minutes later with following temperature drop and pressure rise at about 35 minutes later. Furthermore, the third mode arrived at the airport at about 1840TST, and brought the rainfall peak of 44 $\mathrm{mm} / \mathrm{min}$ at about 50 minutes later as well as temperature drop and pressure rise at about 60 minutes later. The last mode had the most distinct feature in wind variation and rainfall peak as well as the obvious temperature drop and pressure rise. Table 1 describes the time series of passage of three LEWP modes at Makung Airport from 1530TST to 2030TST on 23 July 2014. Based on the upper air sounding profile of Makung Airport weather station at 1200UTC (2000TST) on 23 July 2014 (shown in Figure 10), an evident inversion was identified at the lowest level probably due to the heavy rainfall event in $26 \mathrm{~mm} / \mathrm{min}$ while it was conducted at 1835TST (UTC+8). Therefore, even after the typhoon warning at Makung Airport was terminated at 1740TST, the following significant turbulence and heavy rainfall might affect the flight gesture and reduce the visibility in the lowest atmosphere. 


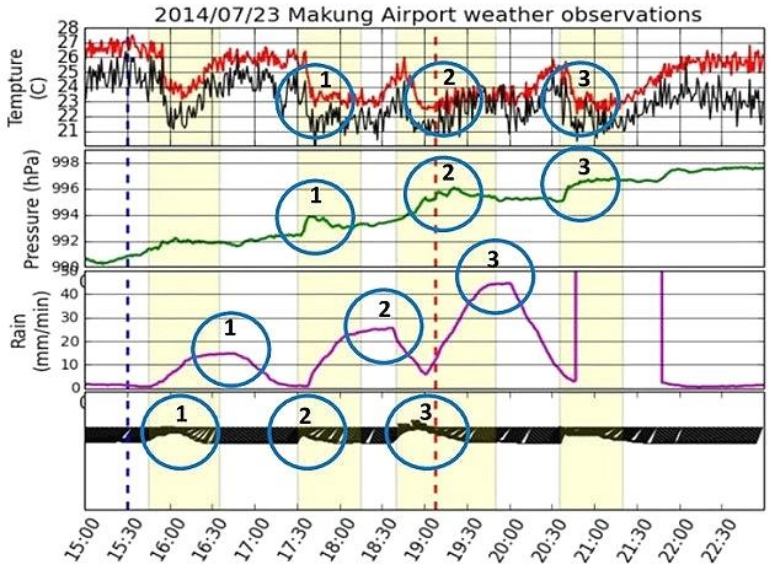

Figure 9. The surface observations measured at the Makung Airport from 1500TST (UTC+8) to 2300TST (UTC+8) on 23 July 2014, including temperature $\left({ }^{\circ} \mathrm{C}\right)$, dew point $\left({ }^{\circ} \mathrm{C}\right)$, pressure $(\mathrm{hPa})$, and rainfall rate $(\mathrm{mm} / \mathrm{min})$. The typhoon warning for Makung Airport was terminated at 1740TST on 23 July 2014, and the red dashed line represents the time (1906:18.9TST, UTC+8) of GE222 crash occurrence.

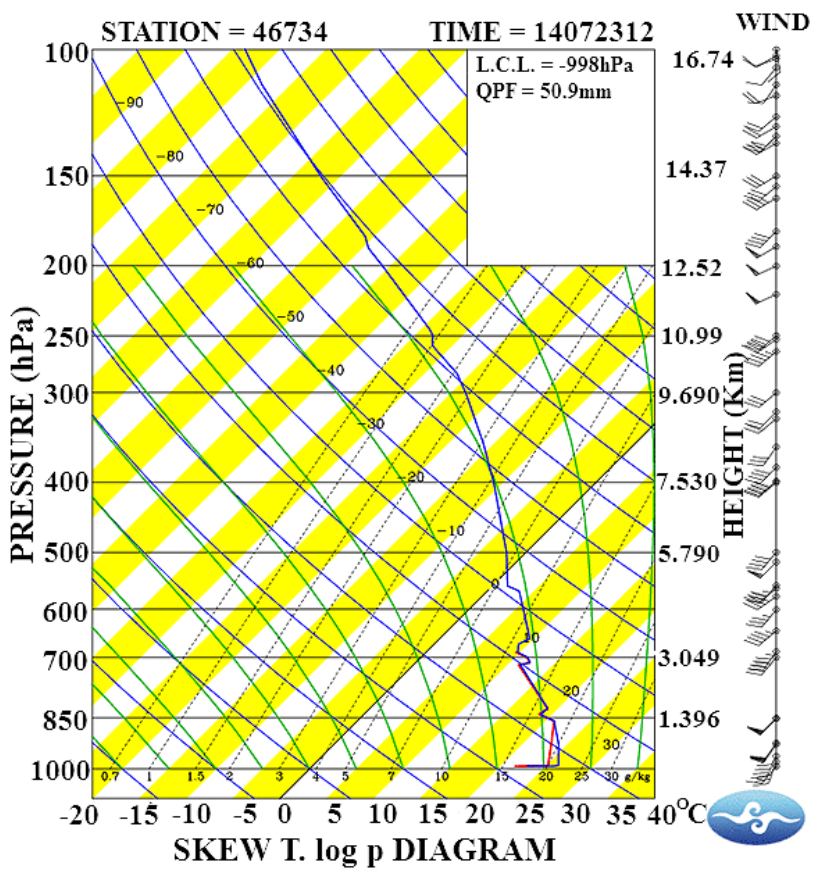

Figure 10. The skew $\mathrm{T}, \log \mathrm{p}$ diagram of Makung Airport weather station at 1200UTC (2000TST) on 23 July 2014. The 2000 hours routine upper air sounding operation was conducted at 1835TST, and an evident inversion was identified at the lowest. (Adopted from Central Weather Bureau)

\section{Doppler Radar Analysis}

In 2014, the weather radar network in southwestern Taiwan included one dual-polarized Doppler radar located at Makung Airport and one operational Doppler radar located at Chiku (not shown). The radar baseline between Makung-Chiku radar sites is $64 \mathrm{~km}$, and the radar specifications of these two radars are shown in Table 2. Doppler velocity data were edited by using the NCAR SOLO II software in order to eliminate noise and unfold velocity. And then, the radar data were interpolated onto a $2 \mathrm{~km} \times 2 \mathrm{~km} \times 0.5 \mathrm{~km}(\mathrm{x}, \mathrm{y}, \mathrm{z})$ grid of a Cartesian coordinate with a proper radius of influence via Cressman interpolation method. The wind field was supposed to be smoother than its origin accordingly. The algorism applied in the estimation includes the downward integration, the boundary condition with $\mathrm{wt}=\mathrm{wb}=0$, and variational adjustment. The retrieved vertical velocity was calculated by continuity equation, setting $\mathrm{w}=0$ at upper boundary with reflectivity less than $10 \mathrm{dBZ}$ and at lower boundary at $0.5 \mathrm{~km}$ level. The detailed methodology and processes for synthesizing wind are described in the study by Lee et al.[11]. Considering the enhanced sampling and limited velocity error variance, the grid setting for interpolating the radar data is also $1.5 \mathrm{~km} \times 1.5 \mathrm{~km} \times 0.5 \mathrm{~km}$ in the Cartesian coordinates $(\mathrm{x}, \mathrm{y}, \mathrm{z})$ designed by Davies-Jones [12]. It should be noted that the underestimation of the vertical velocity is an inevitable problem as there is no reliable low boundary observation below 0.5 elevation angle.

The Dual-Doppler synthesis of Chiku and Makung weather radars at $2 \mathrm{~km}$ level at 0809UTC (1609TST) on 23 July 2014 is shown in Figure 11(a). The radar analysis delineated that the prevailing wind in magnitude of $10 \mathrm{~m} / \mathrm{s}$ at the rear flank of the LEWP was northwesterly during the abrupt wind change period in the first LEWP mode with $\sim 10 \mathrm{~mm} / \mathrm{min}$ rainfall rate illustrated in Figure 9. The vertical cross section perpendicular to this LEWP system was shown in Figure 11(b). The rear-to-front inflow, the vertical convection and the secondary circulation at the rear flank of LEWP were obvious and well organized. Usually, the updrafts occurred at the front edge of LEWP and the downdrafts occurred at the rear of it. Also, the wave-like echoes in maximum intensity were accompanied with great variation of wind direction and wind speed, and resulted in the harmful turbulence to airplanes. During this period, the estimated vertical velocity could reach $-2 \mathrm{~m} / \mathrm{s}$ in maximum, implying an evident downdraft phenomenon at the rear flank.

Table 1. The time series of passage of three LEWP modes at Makung Airport at on 23 July 2014. (Referred from the ASC Aviation Occurrence Report, 2016)

\begin{tabular}{|c|c|c|c|c|c|}
\hline LEWP Mode & $\begin{array}{c}\text { Time of Wind } \\
\text { Change (TST) }\end{array}$ & $\begin{array}{c}\text { Time of Rainfall } \\
\text { Peak (TST) }\end{array}$ & $\begin{array}{c}\text { Time of P Rise } \\
\& \text { T Drop(TST) }\end{array}$ & $\begin{array}{c}\text { Time Lag bet. } \\
\text { Phase 1 \& 2(min) }\end{array}$ & $\begin{array}{c}\text { Time Lag bet. } \\
\text { Phase 2 \& 3(min) }\end{array}$ \\
\hline 1 & 1600,23 July & 1640,23 July & 1740,23 July & 60 \\
\hline 2 & 1735,23 July & 1835,23 July & 1910,23 July & 60 \\
\hline 3 & 1850,23 July & 1940,23 July & 2040,23 July & 50 \\
\hline
\end{tabular}


Table 2. Radar specifications of the Makung and Chiku sites. The letter "D" stands for Doppler mode and "ND" represents non-Doppler mode.

\begin{tabular}{|c|c|c|}
\hline Radar Items & Makung Radar & Chiku Radar \\
\hline Wavelength & $5 \mathrm{~cm}(\mathrm{C}$ band $)$ & $10 \mathrm{~cm}(\mathrm{~S}$ band $)$ \\
\hline Location & $119.63^{\circ} \mathrm{E}, 23.56^{\circ} \mathrm{N}$ & $120.08^{\circ} \mathrm{E}, 23.15^{\circ} \mathrm{N}$ \\
\hline Elevation $(\mathrm{m})$ & 48 & 38 \\
\hline Type & Meteor-1500C & Meteor-1000C \\
\hline Antenna polarization & Dual polarization & Horizontal linear \\
\hline $\begin{array}{c}\text { Scanning range } \\
(\mathrm{km})\end{array}$ & $160(\mathrm{D}), 480(\mathrm{ND})$ & $230(\mathrm{D}), 460(\mathrm{ND})$ \\
\hline $\begin{array}{c}\text { Angular resolution } \\
(\text { degree })\end{array}$ & 1 & 1 \\
\hline $\begin{array}{c}\text { Range resolution } \\
(\mathrm{km})\end{array}$ & $0.5(\mathrm{D}), 1(\mathrm{ND})$ & $0.25(\mathrm{D}), 1(\mathrm{ND})$ \\
\hline Sample size & 100 & $131(\mathrm{D}), 32(\mathrm{ND})$ \\
\hline Ray width $(\mathrm{deg} / \mathrm{s})$ & 15 & 11.36 \\
\hline Nyquist velocity $(\mathrm{m} / \mathrm{s})$ & \pm 37.18 & \pm 20.0 \\
\hline \begin{tabular}{c} 
Pulse width $(\mu \mathrm{s})$ \\
\hline
\end{tabular} & $0.5(\mathrm{D}), 3.0(\mathrm{ND})$ & $0.4(\mathrm{D}), 10.0(\mathrm{ND})$ \\
\hline
\end{tabular}

Furthermore, at the last approach stage of the GE222 aircraft, the radar composite at $3 \mathrm{~km}$ level at 1109UTC (1909LST) shown in Figure 12(a) pointed out the prevailing wind in magnitude of $14 \mathrm{~m} / \mathrm{s}$ became northerly during the clearly abrupt wind change period in the third LEWP mode with $>10 \mathrm{~mm} / \mathrm{min}$ rainfall rate portrayed in Fig. 9. The rear inflow jet $(\sim 14 \mathrm{~m} / \mathrm{s})$ and the downdraft $(\sim$ $-8 \mathrm{~m} / \mathrm{s}$ ) at the rear flank of LEWP became much more intense than those during the first LEWP mode, and the updraft at the front flank was also well organized with speed larger than $4 \mathrm{~m} / \mathrm{s}$ shown in Figure 12(b). Generally, the significant updrafts occurred at the front edge of LEWP and the intense downdrafts occurred at the rear of it. Therefore, it also resulted in the harmful turbulence to airplanes.

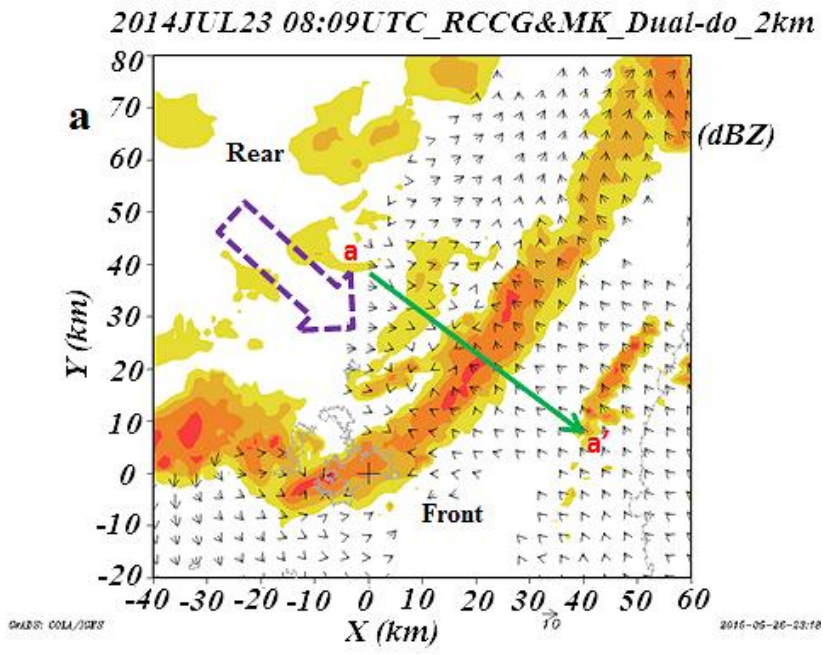

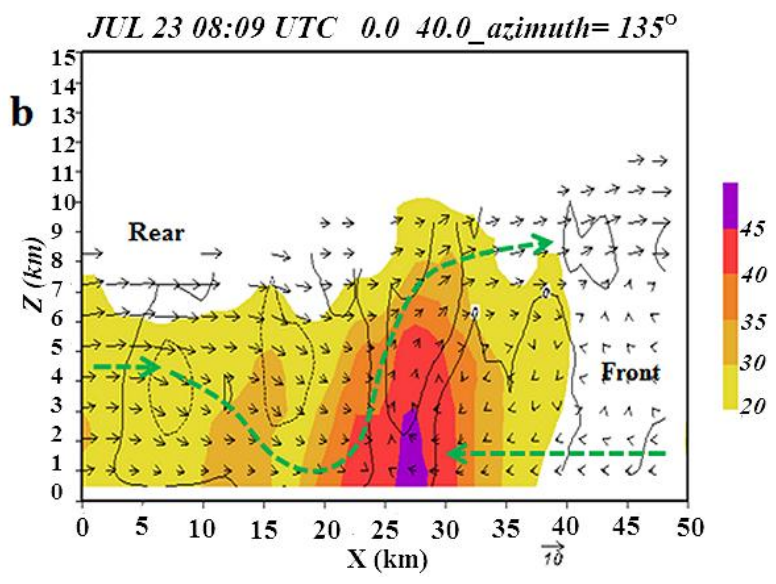

Figure 11. (a) The Dual-Doppler synthesis of Chiku \& Makung weather radars at $2 \mathrm{~km}$ level at 0809UTC (1609TST) on 23 July 2014. The vertical axis is the y-distance $(\mathrm{km})$ and horizontal one represents the $\mathrm{x}$-distance $(\mathrm{km})$ with respective to the Makung radar site which is symbolled by the "+" mark. The a-a' green line stands for the vertical cross section position shown on the panel (b) beginning at the point of $(\mathrm{x}=0 \mathrm{~km}, \mathrm{y}=40 \mathrm{~km})$. The blue dashed arrow represents the rear inflow jet in magnitude of $10 \mathrm{~m} / \mathrm{s}$. (b)The vertical cross section along the a-a' green line on the panel (a) shows the echo intensity $(\mathrm{dBz})$ and the vertical velocity $(\mathrm{m} / \mathrm{s}$ ) with maximum speed of $-2 \mathrm{~m} / \mathrm{s}$. (Adopted and modified from Wei et al.[8])
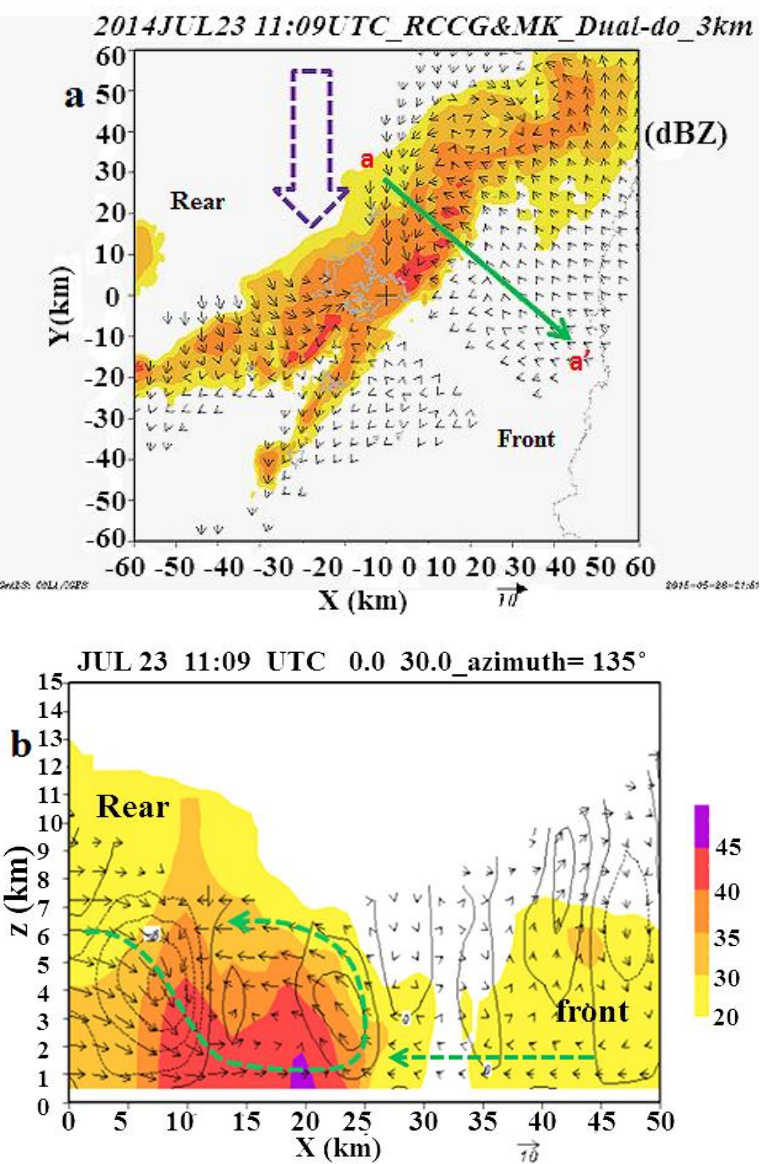

Figure 12. (a) Same as Figure 13(a) except for 1109UTC (1909TST) on 23 July 2014 at altitude of $3 \mathrm{~km}$. The a-a' green line stands for the vertical cross section position shown on the panel (b) beginning at the point of $(x=0 \mathrm{~km}, \mathrm{y}=30 \mathrm{~km})$. The blue dashed arrow represents the rear inflow jet in magnitude of $14 \mathrm{~m} / \mathrm{s}$. (b) Same as Figure 13(b) except the vertical velocity $(\mathrm{m} / \mathrm{s})$ with maximum speed of $-8 \mathrm{~m} / \mathrm{s}$. (Adopted and modified from Wei et al.[8]) 


\section{Combined Weather Situations for the GE222 Aircraft Crash Case}

At 1745:02 TST on 23July 2014, TNA flight GE222 took off from Kaohsiung International Airport for Makung Airport. When the aircraft approached Punghu Island, it was radar vectored by ATC and entered a holding pattern at 1811:17TST due to weather conditions under landing minimum. Therefore, the flight crewmembers were going to face the third LEWP mode shown in Table 1 while conducting the RWY 20 VOR approach. Before landing, the immediate procedures for the QNH (an aeronautical code $\mathrm{Q}$ code) adjustment and the change of flight rolling statue would be necessary for flight crews. Combining the measurements at Makung Airport (Figure 9) and Pinghu weather station (Figure 13), the air had reached $100 \%$ in humidity, the averaged gust wind $15.1 \mathrm{~m} / \mathrm{s}$ and accumulated rainfall rate $26 \mathrm{~mm} / \mathrm{hr}$ with significant wind variation from southwesterly to northwesterly and to southwesterly between 18 19TST just before the GE222 crash occurrence at 1906:18.9TST (UTC+8) on 23 July 2020.

Furthermore, the pilots would be busy at finding out the exact runway due to worse visibility. At the same time, the runway visual range (RVR) measured by AWOS (Automatic Weather Observing System) at Makung airport delivered the last 7 minutes' RVR data before the occurrence (Table 3). The RVR varied significantly from $800 \mathrm{~m}$ (1901TST) to $450 \mathrm{~m}$ (1907TST) in 7 minutes due this short duration and heavy rainfall event with maximum rainfall rate in $1.8 \mathrm{~mm}$ per minute. It means that during the final stage the runway visibility was much below the required landing standard $(1600 \mathrm{~m})$ for the runway $20 \mathrm{VOR}$ approach. Moreover, due to some uncertain reasons, the pilot descended the plane to 280ft at 1905:35TST, below the minimum descent altitude of $330 \mathrm{ft}$, and changed the heading from 208deg to 190deg in the following procedures (Table 4). The possible answers might be resulted from the mesonet weather analysis and the Dopper radar analysis above.

Also, the westerly prevailing wind (wind speed of 27 30 kts) in wind direction of 240 280 degrees between 1900 1906TST based upon the AWOS N 1-min averaged data at Makung Airport) on the runway might bring influential crosswind to the airplane when it was conducting the RWY 20 VOR approach. Furthermore, during the last approach stage, an intense downdraft with the estimated speed of $8 \mathrm{~m} / \mathrm{s}$ embedded inside the LEWP occurred in the vicinity of the flight route. In aviation, the localized downdraft with speed exceeding the descent rate of the aircraft $(3 \sim 4 \mathrm{~m} / \mathrm{s}$ at $100 \mathrm{~m})$ and evident crosswinds to the airplane might endanger the aircraft operations near the ground [13].

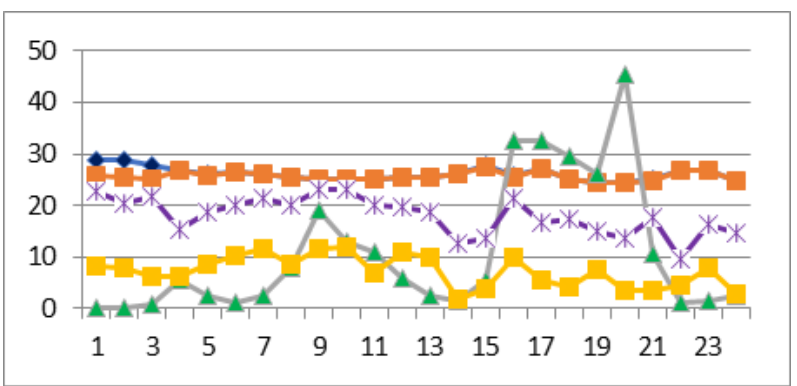

Figure 13. The surface observations measured at the Penghu weather station from 0100TST (UTC+8) to 2400TST(UTC+8) on 23 July 2014 including hourly mean temperature $\left({ }^{\circ} \mathrm{C}\right.$, blue solid line), dew point $\left({ }^{\circ} \mathrm{C}\right.$, brown solid line), wind $\operatorname{speed}(\mathrm{m} / \mathrm{s}$, yellow solid line), gust wind speed $(\mathrm{m} / \mathrm{s}$, purple solid line) and accumulated rainfall rate $(\mathrm{mm} / \mathrm{hr}$, green solid line).

Table 3. The time series of one-minute average RAR measured by AWOS N at Makung Airport on 23 July 2014. TST represents the Taipei Standard Time (UTC+8), and RVR is the Runway Visual Range in unit of meter. (Referred from the ASC Aviation Occurrence Report [6])

\begin{tabular}{|c|c|c|c|c|c|c|c|}
\hline $\begin{array}{c}\text { TIME } \\
\text { (TST) }\end{array}$ & $\begin{array}{c}07 / 23 \\
1901\end{array}$ & $\begin{array}{c}07 / 23 \\
1902\end{array}$ & $\begin{array}{c}07 / 23 \\
1903\end{array}$ & $\begin{array}{c}07 / 23 \\
1904\end{array}$ & $\begin{array}{c}07 / 23 \\
1905\end{array}$ & $\begin{array}{c}07 / 23 \\
1906\end{array}$ \\
\hline $\begin{array}{c}\text { RVR } \\
(\mathrm{m})\end{array}$ & 800 & 650 & 600 & 650 & 600 & 500 \\
\hline
\end{tabular}

Table 4. Selected flight data list for occurrence flight GE222 below $1000 \mathrm{ft}$ on 23 July 2014, including radio height (m), indicated air speed (knot, 1 knot $=1$ nautical mile/hour) and magnetic heading (degs). The minimum descent altitude (MDA) is $330 \mathrm{ft}$ and TST represents the Taiwan Standard Time (UTC+8). (Referred from the ASC Aviation Occurrence Report [6])

\begin{tabular}{|c|c|c|c|c|}
\hline $\begin{array}{c}\text { TIME } \\
\text { (TST) }\end{array}$ & $07 / 23$ & $07 / 23$ & $07 / 23$ & $07 / 23$ \\
190546 & 190549 & $\mathbf{2 2 0}$ & 190608 \\
\hline Radio height (ft) & 190535 & $\mathbf{2 2 5}$ & $\mathbf{1 1 3}$ & $\mathbf{1 1 4}$ \\
\hline $\begin{array}{c}\text { Indicated air speed } \\
\text { (knot) }\end{array}$ & $\mathbf{1 2 0}$ & $\mathbf{1 2 6}$ & $\mathbf{1 2 2}$ & $\mathbf{2 0 8}$ \\
\hline $\begin{array}{c}\text { Magnetic heading } \\
\text { (deg) }\end{array}$ & - & $\mathbf{2 0 8}$ & $\mathbf{1 9 0}$ \\
\hline
\end{tabular}




\section{Conclusion and Discussion}

After Typhoon Matmo(2014) moved into the mainland China at 1500LST on 23 July 2014, the steep gradient of the geopotential height anomaly at the east flank of the typhoon circulation and the friction effect at its lowest levels over land (at the west flank) sketched the dipole wind feature critically. Moreover, the associated outer rainband became well-organized over the Taiwan Strait area. The well-organized LEWP and convective cells embedded within the rainband affected the Makung airport while the typhoon system kept moving north-northwestward. The mesonet surface data analysis told that each echo in the LEWP consisted of several convective cells bringing heavy rainfall and the resulting pressure rise and temperature drop on the ground along the west coast of central Taiwan. The radar analysis delineated that the rear inflow jet, the vertical convection and the secondary circulation at the rear flank of LEWP became more obvious and kept well organized.

According to the Aviation Occurrence Report prepared by Aviation Safety Council (2016), it described that the Makung airport was affected by the outer rainband of Typhoon Matom at the time of the occurrence. At the final approaching stage the weather conditions were not consistent with the encounter of wind shear and downburst. During 1906:00TST and 1906:12TST, the head wind decayed from $19 \mathrm{kts}$ to15 kts, and the right crosswind increased from $27 \mathrm{kts}$ to $30 \mathrm{kts}$. Furthermore, at the last 2 minutes interval, the airplane might encounter turbulence classified as light to moderate level. Conclusively speaking, the meteorological conditions included thunderstorm activities of heavy rain, significant changes in visibility, and abrupt changes in wind direction and speed.

Generally, the preliminary findings in this study are quite similar to those in the ASC report. These three LEWPs caused significant change in wind direction and wind speed accompanied with lagged heavy rainfall, pressure rise and temperature drop. However, the Dual-Doppler synthesis of Chiku and Makung weather radars at $2 \mathrm{~km}$ level tells that the vertical velocity $(\mathrm{m} / \mathrm{s})$ at the rear of the core echo region reached $-2 \mathrm{~m} / \mathrm{s}$ in maximum speed about $25 \mathrm{~km}$ away from the Makung weather radar site at 0809UTC (1609TST) on 23 July 2014 (Figure 11(b)). And three hours later, it became much worse. The vertical cross structure of radar composite at 1109UTC (1909LST) indicated that the downdraft at the rear flank of LEWP became much more intense, and the updraft at the front flank was quite clearer (Figure 12(b)).

In summary, the wind dipole feature of the typhoon circulation after the passage of Taiwan high topography in average altitude of $2000 \mathrm{~m}$ was due to the steep gradient of the geopotential height anomaly at the east flank of the circulation and the friction effect at its lowest circulation over land from the synoptic scale point of view. The typhoon rainband and its related deep convections were developed by the merging mechanism between the typhoon circulation and the southwesterly flow, delivering abundant moisture off the southwest coast of Taiwan. The research results delineated that the LEWPs organized by deep convections featured a key factor on the development of short duration heavy rainfall, low visibility and significant turbulence from the mesoscale point of view. Conclusively speaking, the aircraft faced multiple and severe weather situations, including the intense crosswind, obvious downdraft and extremely low visibility. Therefore, the impact of deep convections inside LEWPs embedded within the typhoon rainband on aviation safety was remarkable, and this case is a good lesson for flight safety. The significant updrafts occurred at the front edge of LEWP and the moderate downdrafts occurred at the rear of it. Much more than that, the right crosswind kept $27 \sim 30 \mathrm{kts}$ at the last approach stage (1906:00 and 1906:12LST). It means the plane faced a multiple and severe weather situation, including the intense crosswind, obvious downdraft and extremely low visibility while the plane was flying in low attitude and slow speed. Therefore, even the typhoon warning for Makung Airport was terminated, but the weather surveillance should proceed in order to avoid regrets. Also, the pilots controlling the passenger aircraft have to realize the threat of severe weather situations, and need to pursue good fortune and avoid disaster.

\section{Acknowledgements}

We are very grateful to Central Weather Bureau and Air Force Weather Wing of Taiwan for preparing the useful weather data and radar data. Also, we appreciate that NOAA/ESRL offers the atmospheric variables plotting approach in use of NCEP/NCAR reanalysis data. In addition, some experts and scholars in meteorology and aviation safety gave constructive suggestions to improve this manuscript.

\section{REFERENCES}

[1] T. H. Hor, C. H. Wei, M.H. Chang and C. S. Cheng. Doppler radar analysis of Typhoon Otto (1998) Characteristics of eyewall and rainbands with and without the influence of Taiwan orography. J. Met. Soc. Japan. Vol.83, No.6, 1001-1023, 2005.

[2] C. H. Wei, Y. C. Chuang, T. H. Hor, C. C. Liao, and N. C. Yeh. Dual Doppler radar investigation of a convective rainband during the impact of the southwesterly monsoonal flow on the circulation of typhoon Morakot (2009). J. Meteor. Soc. Japan, Vol.92, No.4, 363-383, 2014.

[3] C. K. Yu and C. L. Tsai. Structural and surface features of arc-shaped radar echoes along an outer tropical cyclone rainbands. J. Atmos. Sci., Vol.70, 56-72, 2013. 
[4] C. K. Yu, C. Y. Lin, L. W. Cheng, J. S. Luo, C. C. Wu and Y. Chen. The degree of prevalence of similarity between outer tropical cyclone rainbands and squall lines. Sci. Rep., Vol.8, 1-15, 2018.

[5] C. H. Wei, T. H. Hor, J. L. Wang, Y. C. Chuang and T. C. Chen Wang. Mesoscale analysis on the interaction between southwesterly monsoonal flow and circulation associated with Typhoon Morakot (2009). J. Meteor. Soc. Japan, Vol.90, No.5, 617-628, 2012.

[6] Aviation Safety Council. Aviation Occurrence Report, ASC-AOR-16-01-002. 23 July, 2014. TransAsia Airways Flight GE222, ATR72-212A, B-22810. Taiwan Transportation Safety Board, 2016. Online available from https://www.asc.gov.tw/upload/acd_att/ASC-AOR-16-01-0 02-en.pd

[7] C. H. Wei, W. C. Lee, T.H. Hor and M. H. Chang. Evolution and structure of a subtropical mesoscale convective system in East Asia: Single Doppler observations of the line echo wave pattern (LEWP). Journal of Air Force Institute of Technology, Vol.6, No.1, 109-128, 2007.
[8] C. H. Wei, C. C. Liao, and Y. C. Chen. The characteristics of the linear echo wave pattern embedded within the typhoon rainband - in case of Typhoon Matmo. Q. J. of Meteor., Vol.224, 1-6, 2015. (Chinese edition with English abstract)

[9] Central Weather Bureau. Life Weather - FAQ for Typhoon, Online available from https://www.cwb.gov.tw

[10] NOAA/ESRL. Atmospheric Variables Plotting Page, Online available from www.esrl.noaa.gov/psd/data/histdata

[11] C. S. Lee, Y. C. Liu and F. C. Chien. The secondary low and heavy rainfall associated with Typhoon Mindulle (2004). Mon. Wea. Rev., Vol.136, 1260-1283, 2008.

[12] P. R. Davies-Jones. Dual-Doppler radar coverage area as a function of measurement accuracy and spatial resolution. J. Appl. Meteor., Vol.18, 1229-1233, 1979.

[13] T. T. Fujita. Tornadoes and downbursts in the context of generalized planetary scales. J. Appl. Meteor., Vol.38, No. 3, 1511-1534, 1981. 